\title{
Seni Mendeteksi Penyakit Melalui Lidah Dalam Budaya Pengobatan Tradisional Tiongkok
}

\author{
Ni Made Sinarsari ${ }^{1}$, I Gede Sutana ${ }^{2}$ \\ UPTD Puskesmas I Dinas Kesehatan KecamatanDenpasar Utara ${ }^{1}$, \\ STAHN Mpu Kuturan Singaraja ${ }^{2}$ \\ email: sinarsari73@gmail.com ${ }^{1}$, sutanagde@gmail.com² \\ Diterima tanggal 6 Pebruari 2021, diseleksi tanggal 16 Maret 2021, \\ dan disetujui tanggal 30 Maret 2021
}

\begin{abstract}
Traditional medicine is closely related to the culture in which it develops. The art of detecting disease through the tongue is one of the main diagnostic methods in Traditional Chinese Medicine culture that has been applied since the classical times of the Yellow Emperor. Tongue diagnosis in Traditional Chinese Medicine culture is a method for diagnosing disease and disease patterns by visual inspection of the tongue and its various features. As with other diagnostic methods, the diagnosis of the tongue is based on the principle that the outside of the body reflects the inside of the body. The tongue provides important clues that reflect the condition of the internal organs in each patient. In Traditional Chinese Medicine culture, the external structure of the body often reflects the condition of the inner structure and can give an important indication of internal disharmony.
\end{abstract}

Keywords: detecting disease; tongue; traditional medicine; chinese

\section{ABSTRAK}

Pengobatan tradisional berkaitan erat dengan budaya dimana pengobatan tersebut berkembang. Seni mendeteksi penyakit melalui lidah merupakan salah satu metode diagnosa utama dalam budaya pengobatan tradisional Tiongkok yang diterapkan sejak jaman klasik Kaisar Kuning. Diagnosis lidah dalam budaya oengobatan tradisional Tiongkok adalah metode untuk mendiagnosis penyakit dan pola penyakit dengan inspeksi visual lidah yang didasarkan pada prinsip bagian luar tubuh mencerminkan organ tubuh bagian dalam pasien. Dalam budaya pengobatan tradisional Tiongkok, struktur luar tubuh seringkali mencerminkan kondisi struktur dalam dan dapt memberi indikasi penting tentang ketidakharmonisan internal.

Kata kunci: deteksi penyakit; lidah; pengobatan tradisional; tiongkok 


\section{PENDAHULUAN}

Dalam kehidupan sehari-hari, masyarakat begitu sering membicarakan soal kebudayaan. Setiap masyarakat pasti bersentuhan dengan kebudayaan dalam kehidupan sehari-hari. Masyarakat tak mungkin tidak berurusan dengan hasil-hasil kebudayaan. Hal ini setiap hari dapat dilihat ketika masyarakat menggunakan kebudayaan bahkan atau bahkan merusak kebudayaan. Dengan demikian, tidak ada masyarakat yang tidak mempunyai kebudayaan dan sebaliknya tidak ada kebudayaan tanpa masyarakat sebagai wadah dan pendukungnya. Begitu pula dalam budaya kesehatan masyarakat. Kebudayaan kesehatan masyarakat membentuk, mengatur dan mempengaruhi tindakan atau kegiatan suatu kelompok sosial dalam memenuhi kebutuhan kesehatan baik yang berupa upaya mencegah penyakit maupun upaya menyembuhkan diri dari penyakit (Utami \& Harahap, 2019).

Masalah kesehatan sering menjadi problem kehidupan masyarakat sekarang ini. Gangguan kesehatan merupakan kenyataan konsekuensi perilaku yang berwujud tindakan yang disadari atau tidak disadari yang merugikan atau menurunkan derajat kesehatan si pelaku sendiri, orang lain, maupun kelompok. Untuk menyikapi kesehatan yang lebih sempurna biasanya dilakukan melalui dua proses pengobatan, yaitu pengobatan medis dan nonmedis. Jika diamati kondisi masyarakat sekarang, pada umumnya masih lebih percaya pada pengobatan medis. Sistem pengobatan medis ataupun sistem pengobatan modern dengan berbagai kecanggihan sarana, prasarana, dan kemajuan teknologi yang digunakan, ternyata tetap kewalahan mengatasi berbagai penyakit yang diderita oleh masyarakat. Efek obat-obat sintetik modern ternyata juga menyisakan permasalahan dampak kimiawinya. Obat modern dibuat secara sintetis sehingga selalu mengandung risiko yang tinggi terhadap kerusakan, kelainan fungsi, perkembangan, dan pertumbuhan sel tubuh. Hal ini menyebabkan banyak orang menjadi cukup khawatir akan dampak negatif yang ditimbulkan. Berdasarkan pertimbangan tersebut, banyak masyarakat yang masih melirik sistem pengobatan tradisional sebagai jalan alternatif (Nala, 2001).

Dalam bingkai antropologi kesehatan di dunia, budaya pengobatan tradisional yang berasal dari Tiongkok atau sering kita kenal dengan istilah Traditional Chinese Medicine (TCM) merupakan salah satu budaya pengobatan tradisional yang banyak digunakan di dunia. Budaya pengobatan tradisional Tiongkok ini juga diterapkan di Indonesia, yang dalam hal ini digunakan dalam konsep pengobatan akupunktur dan akupresure di Indonesia (Kiswoyo, 1981).

Setiap budaya pengobatan tradisional yang ada di dunia memiliki teknik atau tata cara diagnosanya sendiri. Teknik atau tata cara diagnosa ini digunakan untuk memprediski atau lebih tepatnya untuk menganalisis keluhan penyakit yang diderita oleh pasien yang berobat. Begitu pula dengan budaya kesehatan tradisional Tiongkok. Dalam budaya kesehatan tradisonal 
Tiongkok terdapat beberapa tata cara atau teknik mendiagnosa pasien, salah satunya adalah teknik diagnosa dengan menggunakan lidah. Hal ini hampir serupa dengan teknik diagnosa dalam ilmu kesehatan Ayurweda yang memiliki teknik diagnosa dengan lidah yang dikenal dengan istilah jihva pariksha.

Teknik diagnosis lidah dalam budaya kesehatan tradisional Tiongkok dimulai digunakan sekitar tahun 1350 Masehi. Seni diagnosis lidah memberi informasi penting tentang kesehatan pasien dengan memeriksa lidahnya. Banyak perubahan kesehatan dan keseimbangan tubuh dapat dilihat dengan hanya memeriksa lidah pasien. Pemeriksaan lidah terdiri dari mengamati warna, bentuk, ukuran, dan lapisan di permukaan lidah (coating). Secara umum, lidah yang sehat berwarna merah muda, tidak terlalu kering atau basah, tidak terlalu tipis atau bengkak, dan tanpa cetakan gigi di pinggir lidah atau perubahan warna, dan terdapat lapisan tipis, jelas atau sedikit putih. Belajar mengenai bagian dalam tubuh dengan cara mengamati tanda di luar tubuh adalah tema umum dalam pengobatan tradisional Tiongkok yang masuk akal mengingat pengobatan kuno ini sudah mulai muncul ribuan tahun yang lalu dimana tidak ada mesin X-ray dan MRI. Pengobatan tradisional Tiongkok mengembangkan banyak teknik untuk mempelajari bagian dalam tubuh dengan cara mengamati tanda di luar tubuh (Dubowsky, 2016).

Teknik mendiagnosa penyakit melalui lidah memainkan peran penting dalam mendiagnosis dan kelanjutan pengobatan penyakit. Oleh karena itu, hal ini mulai menarik perhatian sejumlah ahli pengobatan, baik di kedokteran klinis dan biomedik. Namun, teknik diagnosa lidah ini memiliki keterbatasan yang tak terelakkan. Pertama, kompetensi klinis diagnosis lidah ditentukan oleh pengalaman dan pengetahuan dari praktisi. Kedua, faktor pengambilan gambar lidah sangat tergantung pada perbedaan dalam sumber cahaya dan kecerahan gambar, memiliki pengaruh yang besar pada praktisi dalam mendapatkan diagnostik yang tepat dari lidah tersebut. Oleh karena itu, diagnosis lidah erat berkaitan erat dengan identifikasi penyakit serta penentuan tindakan untuk penanganan penyakitnya.

\section{PEMBAHASAN}

\subsection{Gambaran Umum Lidah}

Lidah adalah organ yang sebagian besarnya terdiri dari otot dan dilapisi oleh jaringan lembap berwarna merah muda yang disebut dengan mukosa. Di permukaan lidah, terdapat struktur yang berbentuk seperti rambut-rambut halus bernama papila. Papila inilah yang membuat lidah terasa sedikit kasar saat disentuh. Di atas papila, terdapat ribuan sel pengecap serupa saraf yang menghubungkan saraf di lidah dengan reseptor di otak. Lidah bisa berada tenang di tempatnya, karena ada jaringan dan mukosa yang menempel ke rongga mulut. Bagian 
bawah lidah akan terlihat struktur seperti tali bernama frenulum lingualis yang menghubungkan lidah dengan dasar mulut. Sedangkan di bagian belakang mulut, lidah menempel dengan tulang hyoid. Ukuran rata-rata lidah laki-laki adalah $8,5 \mathrm{~cm}$ sedangkan lidah perempuan 7,9 $\mathrm{cm}$ (Putri, 2020).

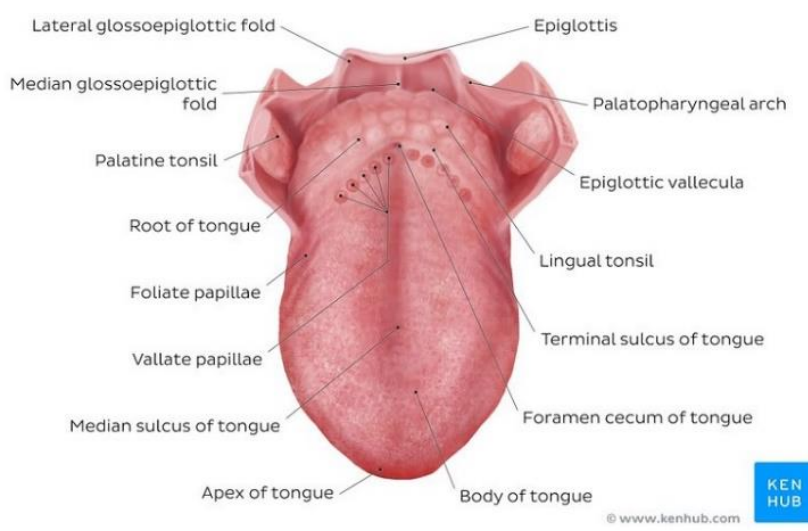

Gambar 1. Gambaran umum lidah

Sumber gambar: (Putri, 2020)

\subsection{Pengamatan Dasar Lidah}

1. Warna lidah

Warna lidah bervariasi dari orang ke orang, tetapi memberikan gambaran yang baik mengenai kesehatan individu secara keseluruhan. Setiap kali lidah berubah warna dari merah muda yang sehat menjadi warna lain, hal ini menunjukkan adanya ketidakseimbangan di dalam tubuh. Berikut adalah beberapa gambaran lidah, diantaranya:

a. Lidah merah menunjukkan terlalu banyak hawa panas di dalam tubuh. Semakin merah warna lidah, maka tubuh semakin panas dan semakin parah penyakit. Beberapa gejala umum untuk hawa panas yang berlebihan di dalam tubuh meliputi: peradangan, migrain, keringat malam, cenderung marah-marah atau mudah tersinggung, infeksi, mata merah atau ruam kulit.

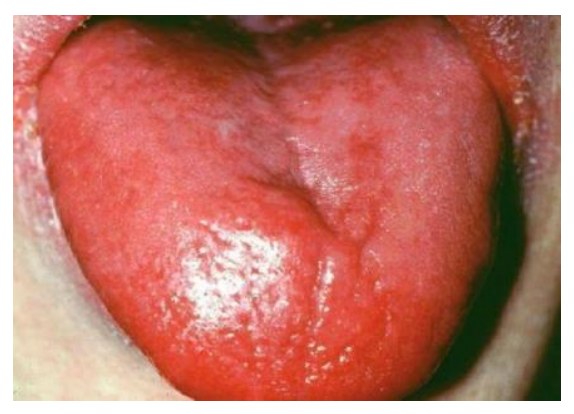

Gambar 2. Lidah Merah

Sumber gambar: (Putri W. M., 2020) 
b. Lidah pucat menunjukkan kurangnya $q i$ dan darah atau tubuh yang dingin. Semakin pucat lidah, maka semakin dingin tubuh atau semakin kurangnya $q i$ dan darah di dalam tubuh. Gejala umum yang terkait dengan lidah pucat adalah: kelemahan, anemia (terutama jika disertai dengan wajah dan bibir pucat), kelelahan, dan kondisi tubuh lemah.

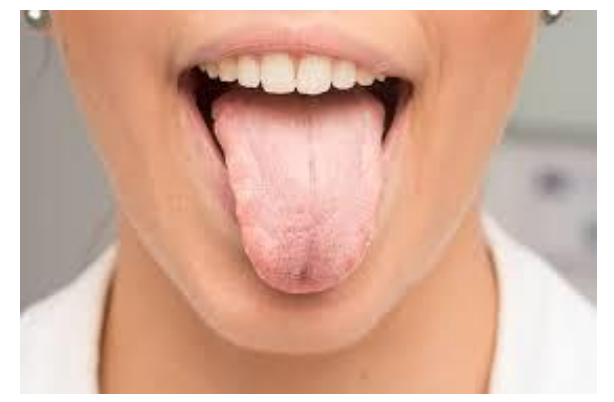

Gambar 3. Lidah Pucat

Sumber gambar: (Savitri, 2020)

c. Lidah berwarna ungu menunjukkan adanya hambatan di suatu tempat atau mungkin lebih dari satu tempat di dalam tubuh. Hambatan ini dianggap sebagai penyumbatan di dalam tubuh. Misalnya, jika seseorang menderita nyeri lutut yang parah, berarti cairan, termasuk darah, tidak mengalir dengan baik ke daerah itu sehingga menyebabkan lutut menjadi nyeri dan meradang. Hambatan tidak hanya akibat nyeri sendi. Hambatan dapat disebabkan oleh masalah peredaran darah, nyeri akibat emosi atau ketidaknyamanan fisik lainnya seperti nyeri dada atau nyeri sebelum menstruasi. Jika masalah terjadi di organ reproduksi, maka wanita tersebut akan sering mengalami darah menstruasi yang lebih gelap disertai dengan bekuan darah pada saat menstruasi.

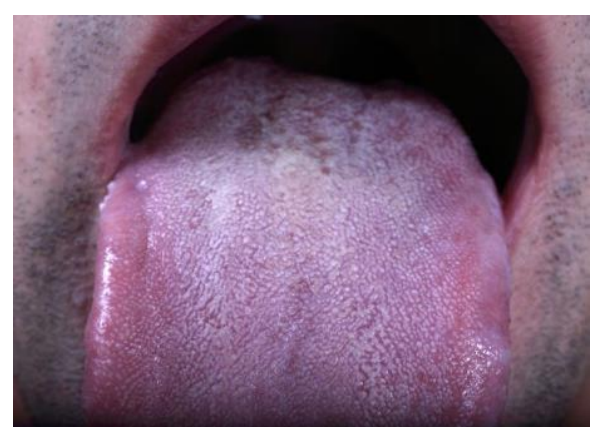

Gambar 4. Lidah Ungu

Sumber gambar: (Sulaeman, 2018)

2. Bentuk dan ukuran lidah

Lidah yang bengkak atau tipis, ada cetakan gigi pada lidah. Ini adalah tanda penting untuk diamati ketika memeriksa lidah. Bentuk dan ukuran lidah menunjukkan metabolisme cairan dalam tubuh. Bentuk danukuran lidah dijelaskan sebagai berikut: 
a. Lidah bengkak menunjukkan bahwa transportasi cairan tubuh tidak bergerak dengan lancar. Melihat hal ini pada orang dengan masalah pencernaan. Jika lidah bengkak dan berwarna ungu, masalah lebih banyak berhubungan dengan sirkulasi darah. Lidah bengkak sering disertai dengan cetakan gigi di pinggir lidah. Hal ini menunjukkan kecenderungan insomnia dan/atau gangguan aliran cairan tubuh.

b. Lidah pendek dan sangat tipis dapat menunjukkan kekeringan atau kekurangan cairan di dalam tubuh. Seringkali ketika seorang wanita mengalami menopause, lidahnya menjadi lebih kering serta berwarna lebih merah. Hal ini terjadi karena pada saat itu darah berhenti mengalir (darah adalah cairan), si wanita mengalami "pemanasan" dirasakan sebagai rasa terbakar di wajah (Harlan, 2009).

3. Bentuk Lidah dan diagnosanya

Dalam mengamati bentuk lidah yang diamati adalah gemuk atau kurus, serta kasar dan licinnya lidah (Kemenkes RI, 2012).

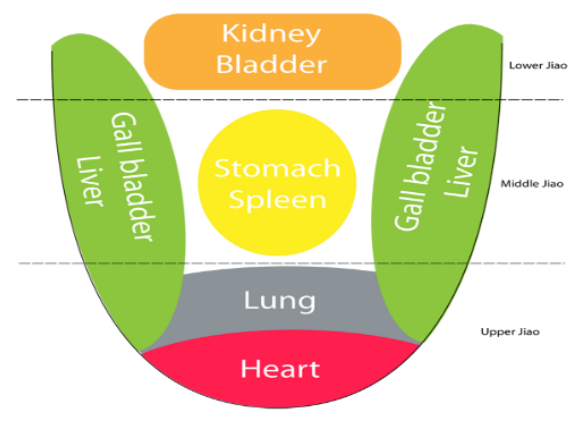

Gambar 5. Pembagian lidah dalam pengobatan tradisional Tiongkok Sumber gambar: (Aribowo, 2011).

\begin{tabular}{|l|l|}
\hline \multicolumn{1}{|c|}{ Bentuk Lidah } & \multicolumn{1}{|c|}{ Diagnosa } \\
\hline Lidah yang kasar apapun bentuknya & Sindrom She/berlebih \\
\hline Lidah yang licin & Sindrom Xi/kekurangan. \\
\hline $\begin{array}{l}\text { Lidah yang gemuk atau lebih besar } \\
\text { dari normal }\end{array}$ & $\begin{array}{l}\text { Adanya genangan air atau lembab di dalam } \\
\text { tubuh. }\end{array}$ \\
\hline Lidah putih, pucat, gemuk dan licin & Kekurangan Yang/panas di limpa dan ginjal. \\
\hline $\begin{array}{l}\text { Lidah merah dan gemuk dengan } \\
\text { selaput kuning }\end{array}$ & $\begin{array}{l}\text { Adanya patogen lembab dan panas di dalam } \\
\text { limpa dan lambung atau adanya dahak }\end{array}$ \\
\hline Lidah gemuk dan merah & Curiga adanya keracunan. \\
\hline
\end{tabular}




\begin{tabular}{|l|l|}
\hline Lidah kurus dan tipis & Kekurangan pasokan Chi dan darah \\
\hline $\begin{array}{l}\text { Permukaan lidah muncul bintik- } \\
\text { bintik/papillae }\end{array}$ & Serangan patogen panas yang berat sekali. \\
\hline $\begin{array}{l}\text { Binti-bintik/papillae muncul di ujung } \\
\text { lidah }\end{array}$ & Panas/api di jantung membara \\
\hline $\begin{array}{l}\text { Binti-bintik/papillae muncul di } \\
\text { pinggir lidah }\end{array}$ & Api dari hati dan kandung empedu membara \\
\hline $\begin{array}{l}\text { Bintik-bintik/papillae muncul di } \\
\text { tengah-tengah lidah }\end{array}$ & Patogen panas berada di lambung atau usus \\
\hline Lidah belah berwarna putih pucat & Chi dan darah tidak cukup \\
\hline Lidah belah berwarna merah & Yin/dingin kurang dan api membara \\
\hline Lidah licin bagai cermin & $\begin{array}{l}\text { Yin/cairan dari lambung sudah kering/penyakit } \\
\text { sudah parah }\end{array}$ \\
\hline Lidah licin pucat & Limpa dan lambung sudah lemah sekali \\
\hline $\begin{array}{l}\text { Lidah licin dan berwarna merah } \\
\text { kehitaman }\end{array}$ & Cairan sudah kering \\
\hline Pingir lidah tampak lekukan bagaikan & $\begin{array}{l}\text { Limpa lemah dan terdapat patogen lembab } \\
\text { didalam tubuh }\end{array}$ \\
\hline Sariawan Lidah & $\begin{array}{l}\text { Patogen api di jantung } \\
\text { membara keatas }\end{array}$ \\
\hline
\end{tabular}

Tabel 1. Bentuk dan diagnosa lidah

4. Lapisan di permukaan (coating) lidah

Ketebalan lapisan dan warna lidah adalah penting untuk diperhatikan. Lapisan di permukaan lidah jauh lebih cepat berubah daripada lidah itu sendiri. Perlu diingat juga bahwa makanan dan minuman akan memengaruhi warna lapisan lidah secara sesaat, dan perokok mudah terdeteksi karena adanya lapisan kuning. Beberapa jenis lapisan lidah, diantaranya:

a. Lapisan yang tebal pada permukaan lidah sering menunjukkan penyakit yang menyerang tubuh berasal dari lingkungan luar tubuh, seperti flu, virus atau hawa dingin. Jika lapisan ini semakin tebal ke arah belakang lidah, berarti penyakit akan berlangsung lama.

b. Lapisan yang tipis pada permukaan lidah sering disebabkan oleh kekeringan. Wanita 
yang mengalami menopause dapat memiliki lapisan yang tipis pada permukaan lidah atau tanpa pelapis disertai lidah yang tipis dan berwarna merah karena perubahan hormon dan kekurangan cairan tubuh.

c. Lapisan putih tebal pada permukaan lidah menunjukkan adanya penyakit karena hawa dingin. Contohnya: kelelahan, mencret, atau kembung, menggigil dan dahak yang jernih.

d. Lapisan kuning pada permukaan lidah menunjukkan adanya hawa panas. Seseorang menderita hawa dingin yang jahat disertai nyeri tenggorokan, berkeringat, dahak berwarna kuning dan demam, maka penyakitnya berhubungan dengan hawa panas.

e. Lapisan abu-abu atau hitam yang langka pada permukaan lidah menunjukkan kondisi yang ekstrim;

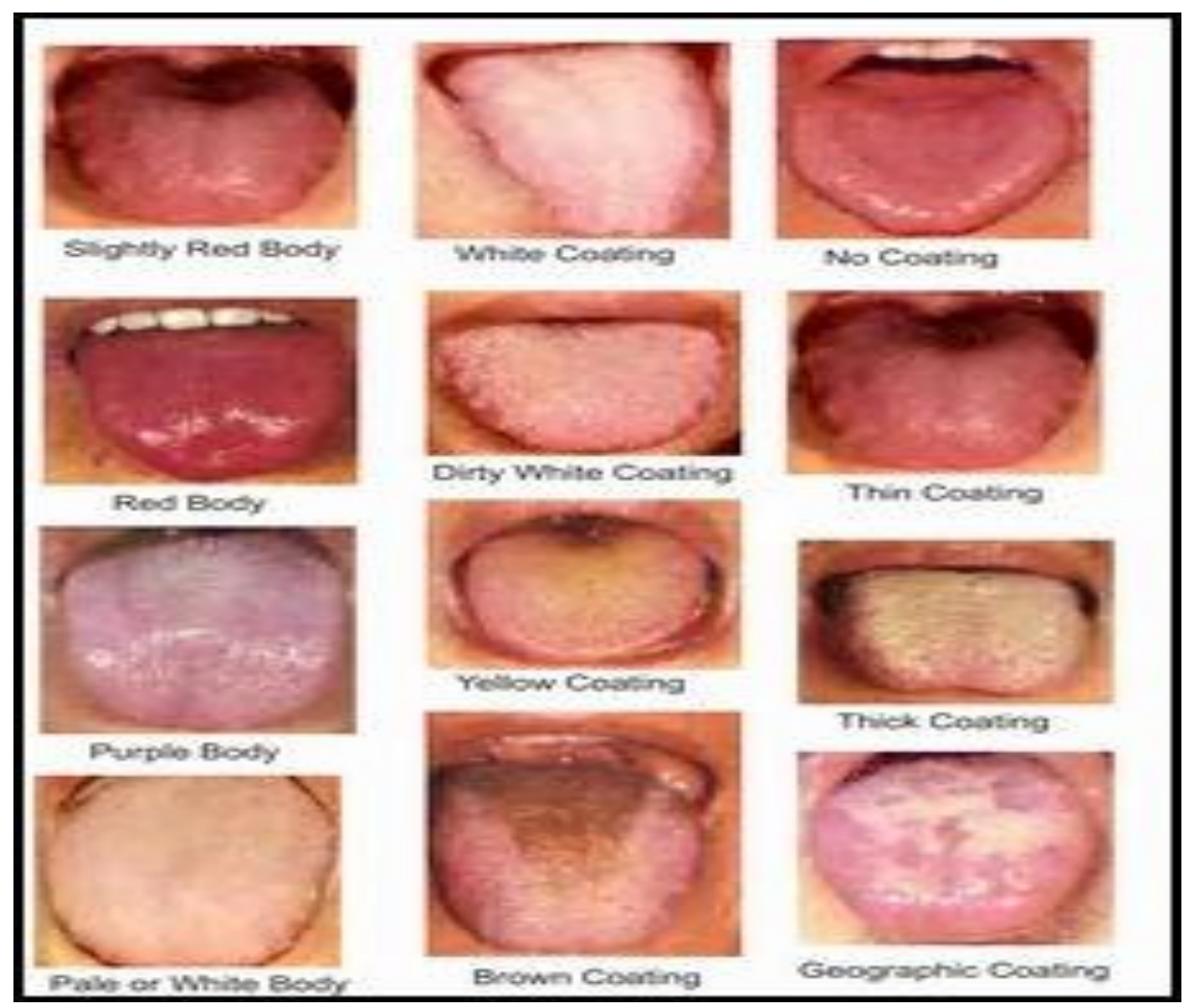

Gambar 6. Lapisan Permukaan Lidah

Sumber gambar: (Aribowo, 2011)

\subsection{Teknik pemeriksaan lidah dalam pengobatan tradisional Tiongkok}

Dalam pengamatan lidah, yang perlu diperhatikan adalah cahaya, postur menjulurkan lidah, dan perubahan selaput lidah. Pada waktu pemeriksan, lidah perlu dijulurkan keluar mulut, tubuh lidah harus lentur, jangan tegang, permukaan datar, tidak menekuk keatas, atau bawah, jangan dijulurkan terlalu lama karena akan mempengaruhi warna tubuh lidah. Pada waktu mengamati lidah, paling baik digunakan cahaya alamiah yang langsung mengenai lidah (Harlan, 2009). 


\section{PENUTUP}

Lidah adalah salah satu organ penting dalam tubuh manusia. Lidah merupakan organ yang sebagian besarnya terdiri dari otot dan dilapisi oleh jaringan lembap berwarna merah muda yang disebut dengan mukosa. Di permukaan lidah, terdapat struktur yang berbentuk seperti rambut-rambut halus bernama papila. Dalam pengamatan lidah, ada beberapa hal penting yang harus diperhatikan, diantaranya: (1) warna lidah; (2) bentuk dan ukuran lidah; (3) bentuk lidah dan diagnosanya; serta (4) lapisan di permukaan (coating) lidah. Diagnosa dengan melakukan pengamatan atau inspeksi pada lidah juga memerluka teknik agar memperoleh hasil yang akurat. Dalam pengamatan lidah, yang perlu diperhatikan adalah cahaya, postur menjulurkan lidah, dan perubahan selaput lidah. Pada waktu pemeriksan, lidah perlu dijulurkan keluar mulut, tubuh lidah harus lentur, jangan tegang, permukaan datar, tidak menekuk keatas, atau bawah, jangan dijulurkan terlalu lama karena akan mempengaruhi warna tubuh lidah. Serta penggunaan cahaya alamiah yang langsung mengenai lidah merupakan cahaya terbaik yang dapat digunakan untuk mengamati lidah.

\section{DAFTAR PUSTAKA}

Aribowo, B. (2011, Oktober 3). Diagnosis Lidah (2) : Warna Lidah. Retrieved from Klinik Alang-Alang: http://klinikalangalang.blogspot.com/2011/10/diagnosis-lidah-2-warnalidah.html

Dubowsky, J. (2016, Oktober 11). Memahami Diagnosis Lidah dalam Pengobatan Tiongkok. Retrieved from http://www.erabaru.net/2016/10/11/memahami-diagnosis-lidah-dalampengobatan-tiongkok/

Harlan, J. (2009). Akupunktur Kebidanan. Jakarta: Penerbit Gunadharma.

Kemenkes RI. (2012). Modul Orientasi Akupresure Bagi Petugas Puskesmas. Jakarta: Dirjen Yankestradkom.

Kiswoyo, K. (1981). Teori dan Praktek Ilmu Akupunktur. Jakarta: PT. Gramedia.

Nala, N. (2001). Ayurveda Ilmu Kedokteran Hindu. Denpasar: Upada Sastra.

Putri, N. H. (2020, Februari 11). Mengenal Bagian-bagian Lidah, Tipe, dan Fungsi Lengkapnya. Retrieved from SehatQ: https://www.sehatq.com/artikel/mengenal-si-pengecap-rasa-inibagian-bagian-lidah-dan-fungsinya

Putri, W. M. (2020, Mei 26). Cek Kondisi Kesehatan Anda dari Warna Lidah. Retrieved from Klik Dokter: https://www.klikdokter.com/info-sehat/read/3147580/cek-kondisikesehatan-anda-dari-warna-lidah 
Savitri, T. (2020, Desmber 18). Lidah Berwarna Putih? Ini 9 Penyebab dan Cara Mengatasinya! Retrieved from Hallo Sehat: https://hellosehat.com/gigi-mulut/gusi-mulut/penyebablidah-putih/\#gref

Sulaeman, S. (2018, April 6). Menebak Kondisi Kesehatan Seseorang Lewat Lidah. Retrieved from Detik Health: https://health.detik.com/fotohealth/d-3957650/menebak-kondisikesehatan-seseorang-lewat-lidah/8

Utami, T. N., \& Harahap, R. A. (2019). Sosioantropologi Kesehatan: Integrasi Budaya dan Kesehatan. Jakarta: Prenadamedia Group. 